DOI: 10.17707/AgricultForest.62.4.17

\begin{abstract}
Siniša OZIMEC, Tihomir FLORIJANČIĆ, Marijan KURTOVIĆ, Milić ČUROVIĆ, Dragan GAČIĆ, Ivica BOŠKOVIĆ ${ }^{I}$
\end{abstract}

\title{
HABITAT CONDITIONS FOR WILDLIFE MANAGEMENT IN THE DINARIC REGIONS OF CROATIA AND MONTENEGRO
}

\begin{abstract}
SUMMARY
Hunting is an important socio-economic activity, particularly in rural areas. Characteristics and quality of habitat are important in the sustainable management of game animals and wildlife conservation. Three hunting grounds were analysed and their habitat composition was compared with regard to abundance of main game animal species. Hunting ground VIII/2 "Bjelolasica" is located in Gorski kotar region; XVII/6 "Maglaj-Cista" in the inland of middle Dalmatia; and hunting ground "Dragišnica" is located in northern part of Montenegro.
\end{abstract}

Keywords: habitat, hunting ground, Dinarides, Croatia, Montenegro

\section{INTRODUCTION}

Habitat represents an area in which individual organism or population of plants and animals lives in interaction with their environment. The protection of habitats makes an integral part of the nature protection in the European Union, based on the Council Directive 92/43/EEC of 21 May 1992 on the Conservation of Natural Habitats and of Wild Fauna and Flora (The Habitats Directive).

The Dinarides mountain chain is extending in NW-SE direction over 650 $\mathrm{km}$ in length and over $150 \mathrm{~km}$ wide (Mihevc et al., 2010). It consists of more than 200 mountains shared among seven countries: Slovenia, Croatia, Bosnia and Herzegovina, Montenegro, Serbia, Kosovo and Albania. The Dinarides mountain system is divided into three morphostructural zones: Inner, Central and Outer Dinarides (Bognar, 2008). The highest elevations occur in the Central zone: Snežnik (1,796 m), Risnjak (1,528 m), Velika and Mala Kapela, Plješivica (1,657 $\mathrm{m})$, Velebit $(1,758 \mathrm{~m})$, Dinara $(1,913 \mathrm{~m})$, Vitorog $(1,907 \mathrm{~m})$, Vran, Čvrsnica (2,228 m), Prenj (2,155 m), Bjelašnica $(2,067 \mathrm{~m})$, Jahorina, Lelija, Maglić, Durmitor $(2,522 \mathrm{~m})$, Tara, Njegoš $(1,721 \mathrm{~m})$, Orjen $(1,895 \mathrm{~m})$, and Lovćen

\footnotetext{
${ }^{1}$ Tihomir Florijančić (corresponding author: tflorijanc@pfos.hr), Siniša Ozimec, Marijan Kurtović Ivica Bošković, Josip Juraj Strossmayer ,University of Osijek, Faculty of Agriculture in Osijek, Osijek, CROATIA, Milić Čurović, University of Montenegro, Biotechnical Faculty, Podgorica, MONTENEGRO, Dragan Gačić, University of Belgrade, Faculty of Forestry, Belgrade, SERBIA Paper presented at the International Conference "Sustainable development of mountain areas Experiences, challenges and perspectives" 14-16 September 2016, Žabljak Montenegro.

Notes: The authors declare that they have no conflicts of interest. Authorship Form signed online.
} 
$(1,749 \mathrm{~m})$. The main part of the Dinarides is formed of Mesozoic and Tertiary rocks, mostly limestone and dolomite. Due to dissolution of these rocks, a typical karst landscape and relief, with numerous surface and underground features appear.

Characteristics and quality of habitat are important in the sustainable and cost effective management of wildlife, including those wild species classified as game animals. Three hunting grounds, situated in the Dinaric regions of Croatia and Montenegro, were selected for analyses and comparison of habitat structure and suitability for the management of main game species. From Croatia: VIII/2 "Bjelolasica", located in Gorski kotar region and XVII/6 "Maglaj-Cista" in the inland, continental part of middle Dalmatia; and hunting ground "Dragišnica" from Montenegro, located in northern part of the country, bordering to the National Park "Durmitor".

\section{Study area}

\section{MATERIALS AND METHODS}

Hunting ground VIII/2 "Bjelolasica" is located in the western Croatia, in the southern part of Gorski kotar region; XVII/6 "Maglaj-Cista" in the middle Dalmatia; and hunting ground "Dragišnica" from Montenegro is located in northern part of the country (Figure 1).

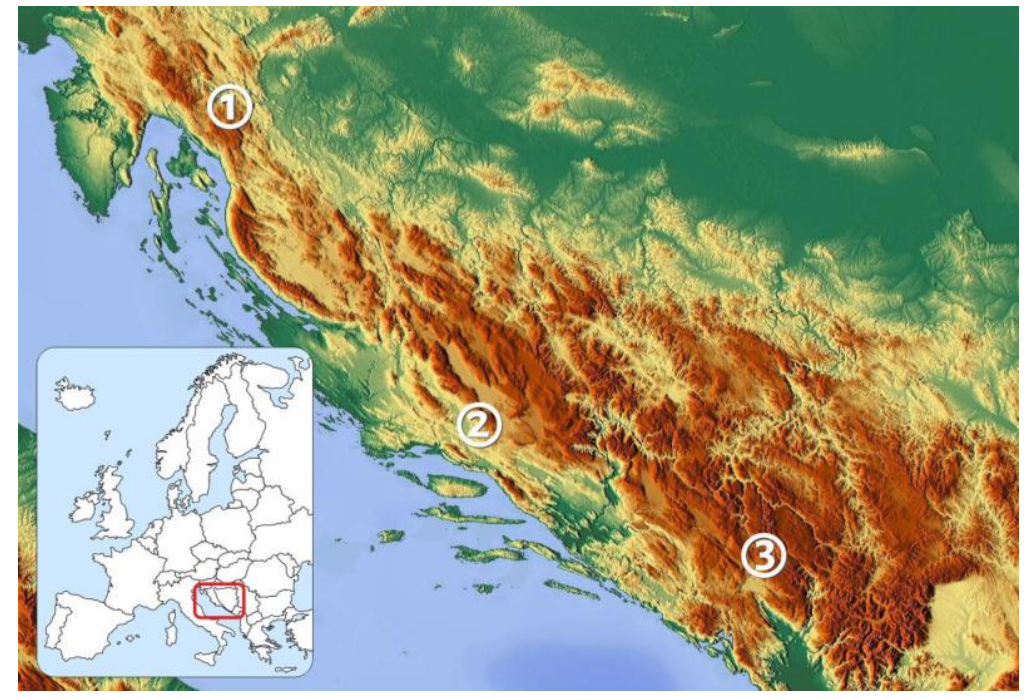

Figure 1. Map of the Dinarides mountain system with position of the surveyed hunting grounds in Croatia (1="Bjelolasica"; $2=$ "Maglaj-Cista") and Montenegro (3="Dragišnica")

Hunting ground "Bjelolasica" (total surface 30,458 ha) is a typical Dinaric hunting ground. Altitudinal range is $350 \mathrm{~m}-1,534 \mathrm{~m}$ (Mt. Bjelolasica summit), 
and mean altitude is $942 \mathrm{~m}$. Mean air temperature is $7.2{ }^{\circ} \mathrm{C}$; annual amount of precipitation is $1,999 \mathrm{~mm}$ and mean number of days with snow cover is 82 days.

Gorski kotar region with $60 \%$ forest cover is the most wooded part of Croatia. Some parts remained as primeval due to their inaccessibility and are protected at national level, such as Risnjak National Park (Ozimec et al., 2010).

Hunting ground "Maglaj-Cista" (total surface of 9,558 ha) is situated at a typical rugged karst plateau, with shaped flat karst fields, and surrounded by hills high ca. $800 \mathrm{~m}$. Altitudinal range is $397 \mathrm{~m}-928 \mathrm{~m}$ (Mt. Maglaj summit), and mean altitude is $663 \mathrm{~m}$. Mean air temperature is $13.2{ }^{\circ} \mathrm{C}$; annual amount of precipitation is $1,300 \mathrm{~mm}$ and mean number of days with snow cover is 8 days.

Hunting ground "Dragišnica" (total surface of 9,795 ha) belongs into Northern hunting sector of Montenegro, comprising NW part of the Municipality of Šavnik. Altitudinal range is $651 \mathrm{~m}-1,998 \mathrm{~m}$ (summit Ogorjeli krš), and mean altitude is $1,890 \mathrm{~m}$. Mean air temperature is $4.6{ }^{\circ} \mathrm{C}$, annual amount of precipitation is $1,456 \mathrm{~mm}$ and mean number of days with snow cover is 58 days.

\section{Data collection and analyses}

Main sources of data were Hunting Management Plans of the surveyed hunting grounds. This is a document which contains data on following: land surface structure; description of vegetation and habitats; assessment of habitat quality for game animals; population structure and guidelines for management with game animals.

\section{Main game species}

\section{RESULTS AND DISCUSSION}

An inventory list of main game animals present in the surveyed hunting grounds is shown in Table 1.

Table 1. List of main game animals and their population size in the hunting grounds

\begin{tabular}{|c|c|c|c|}
\hline \multirow{2}{*}{ Game species } & \multicolumn{3}{|c|}{ Hunting ground } \\
\cline { 2 - 4 } & \multicolumn{2}{|c|}{ Croatia } & Montenegro \\
\cline { 2 - 4 } & Bjelolasica & Maglaj -Cista & Dragišnica \\
\hline Red deer (Cervus elaphus) & 130 & & \\
\hline Roe deer (Capreolus capreolus) & 160 & 32 & 46 \\
\hline Wild boar (Sus scrofa) & 110 & 24 & 25 \\
\hline Brown bear (Ursus arctos) & 100 & & 6 \\
\hline Grey wolf (Canis lupus) & & & 15 \\
\hline Chamois (Rupicapra rupicapra) & & & 180 \\
\hline European hare (Lepus europaeus) & 70 & 180 & 15 \\
\hline European badger (Meles meles) & 90 & 12 & 60 \\
\hline Beech marten (Martes foina) & 60 & 10 & 50 \\
\hline Red fox (Vulpes vulpes) & 30 & 10 & 12 \\
\hline Eurasian jay (Garulus glandarius) & 150 & 20 & \\
\hline Western capercaillie (Tetrao urogallus) & & & 84 \\
\hline Rock partridge (Alectoris graeca) & & & \\
\hline
\end{tabular}




\section{Habitat composition and distribution}

In the "Bjelolasica" hunting ground, forest habitats cover 24,279 ha, and dominate with $81 \%$ of total surface. Dominating is mixed Dinaric beech and fir forest (Omphalodo-Fagetum) which is distributed over 150,000 ha in the Croatian Dinarides area (Vukelić, 2012). It thrives at altitudes 600-1,300 m. European beech (Fagus sylvatica) is an important food source to large and small mammals. Beechnuts have about the same protein content as corn but five times more the fat content. Diverse shrubs and deciduous trees provides valuable food source to red deer and roe deer. Sub-alpine beech forest with platain leafed buttercup (Ranunculo platanifolii-Fagetum) thrives at altitude 900-1,400 m. Tree layer is completely dominated by the beech, which provides sufficient food source to wild animals. Acidophilic fir forest with hard fern (Blechno-Abietetum) grows on silicate rocks and podzolic soils at altitudes $600-900 \mathrm{~m}$. The dense young-growth of conifers makes a good shelter for all big game animals. Calciphilic Dinaric fir forest on limestone blocks (Calamagrostio-Abietetum) growth at altitude above $1,100 \mathrm{~m}$, on sunny and warm slopes consisting of large limestone blocks. Due to configuration and inaccessibility this is a place where brown bear (Ursus arctos) usually makes his dense. Stands of dwarf mountain pine (Pinus mugo) are making the upper boundary of forest vegetation in Croatian Dinarides. It thrives at altitude above 1,400 m, where climate conditions are very harsh with high and long-lasting snow cover. This association Hyperico grisebachii-Pinetum mugi is characteristic for the Northern Dinarides in Slovenia and Croatia (Čarni and Mucina, 2015).

Grassland in the hunting ground "Bjelolasica" comprises meadows and pastures on surface of 4,724 ha which makes $16 \%$ of total surface. Mountain meadows of upright brome on calcareous substrate from the vegetation alliance Bromion erecti have high fodder value in diet of wild animals, mainly herbivores. Today, surfaces with natural or semi-natural meadows are largely reduced, and progression towards forest growth is present. Subalpine calcareous grassland from the vegetation class Seslerietalia juncifoliae is present on the highest peaks of the Dinarides mountains, above the vegetation belt of dwarf mountain pine.

In the hunting ground "Maglaj-Cista" forest habitats covers 8,057 ha and dominates with $78 \%$ of total surface. Thermophilous, deciduous forest and scrubs of pubescent oak (Quercus pubescens) and oriental hornbeam (Carpinus orientalis), classified as association Querco-Carpinetum orientalis, are specific for the lower submediterranean vegetation zone (Vukelić et al., 2008). This forest is rarely developed in shape of complete forest but mostly as degradation stage of tall or high scrubs. In the higher, Mediterranean-montane belt, the climate is even colder and relatively more humid. Mixed forest and scrub of pubescent oak and hop hornbeam (Ostrya carpinifolia), classified as association Ostryo-Quercetum pubsecentis, are present mostly as degradation stage of tall scrubs.

Thermophilous and xerophilous scrubs of eastern submediterranean region (Rhamno-Paliuretum), consists mainly of thorny and spinous plants, such as: the Jerusalem thorn (Paliurus spina-christi) and Rhamnus intermedia. 
Grassland in the hunting ground "Maglaj-Cista" comprises meadows and pastures on surface of 614 ha which makes $7 \%$ of total surface. Dry rocky grasslands, classified into associations: Stipo-Salvietum officinalis and FestucoKoelerietum splendentis, are among the most frequent grassland communities in the Mediterranean region, and widely distributed along the whole of the Croatian part of the Adriatic coast (Topić and Vukelić, 2009). They usually develops on hill slopes on sparse soil, surface of which is dominated by stable or unstable stone, and exposed to the impact of the wind, great oscillations in temperature and to a paucity of water, which is not retained in the permeable and skeletal soil. These grasslands give good food sources as well as for domestic (sheep and goats) as for the wild animals (European rabbit and rock partridge).

In the hunting ground "Dragišnica" forest habitats covers 3,057 ha and makes $31 \%$ of total surface. Thermophilous forest (Ostryo-Quercetum petraeae) of common (Quercus petraea) and hop hornbeam (Ostrya carpinifolia) thrives on steep terrain such as canyon of the Komarnica River. Mixed forest of moesian beech (Fagus moesiaca) and fir (Abieti-Fagetum moesiace) dominates in the altitudinal range $800-1,900 \mathrm{~m}$, on calcareous substrate. Mixed forests of beech, fir and spruce (Piceeto-Abieti-Fagetum s. lat.) are reported from Montenegro (Čurović et al, 2011). Subalpine beech forest with sycamore (Fageto-Aceretum visianii) thrives in high altitudinal zone 1,400-1,800 m. Stands of dwarf mountain pine (Pinus mugo) are present at highest part of mountains, at altitude 1,800$2,400 \mathrm{~m}$, where climate conditions are extremely harsh. According to recent findings (Čarni and Mucina, 2015), plant communities dominated by Pinus mugo in Bosnia and Herzegovina and Montenegro are classified into association Lilio bosniacae-Pinetum mugo.

Grassland in the hunting ground "Maglaj-Cista" comprises meadows and pastures on surface of 3,156 ha which makes $31 \%$ of total surface. Diverse alpine and subalpine calcareous grasslands are classified into associations: StachydiFestucetum pseudoxanthynae, Genisto-Festucetum spadicaeae and FestucoAgrostietum.

\section{Management of main game animals}

Diversity of habitats in all three surveyed hunting grounds is most suitable for management of the following game species: roe deer, wild boar, European hare, European badger, beech marten, and red fox.

Good habitat conditions for managing population of red deer and particularly brown bear are present in the hunting ground "Bjelolasica" in Gorski kotar. In the hunting ground "Dragišnica" in Montenegro, habitat conditions are good for managing the population of brown bear, grey wolf and western capercaillie.

Submediterranean rocky grasslands in the hunting ground "Maglaj-Cista" in middle Dalmatia are the high quality habitats for managing the population of European hare and winged game, such is the rock partridge. 


\section{CONCLUSIONS}

Characteristics and quality of habitats are important preconditions for protection, conservation and management of wildlife, as well as of free-living animal species as those classified as game animals. Structure and distribution of habitats supports rich biological diversity in the regions of Croatia and Montenegro which belongs into the Dinarides mountain chain.

Diversity of habitats and their good quality is essential for the sustainable and effective management of big and small game animals in the hunting grounds.

\section{REFERENCES}

Bognar, A. (2008.): Basic geomorphological characteristics of the Dinarides mountain system. Acta GGM Debrecina, 3:1 21-125.

Čarni, A., Mucina, L. (2015): Validation and typification of some south-European syntaxa. Hacquetia 14(2): 289-299.

Čurović, M., Medarević, M., Pantić, D. \& Spalević, V. (2011): Mayor types of mixed forests of spruce, fir and beech in Montenegro. Austrian Journal of Forest Science, 128 (2): 93-111..

Mihevc, A., Prelovšek, M., Zupan Hajna, N. (2010): Introduction to the Dinaric Karst. Inštitut za raziskovanje krasa, Postojna.

Ozimec, S., Bošković, I., Florijančić, T., Jelkić, D., Opačak, A., Puškadija, Z., Labak, I. (2010): The lichen flora of Risnjak National Park.

Ozimec, S, Padavić, J., Florijančić, T., Bošković, I. (2014): Monitoring of wildlife habitats in Dinaric karst region of Croatia. Journal of Environmental Protection and Ecology, 15(3): 889-896.

Topić, J., Vukelić, J. (2009): Priručnik za određivanje kopnenih staništa u Hrvatskoj prema Direktivi o staništima EU. Državni zavod za zaštitu prirode, Zagreb.

Vukelić, J. (2012): Šumska vegetacija Hrvatske. Sveučilište u Zagrebu, Šumarski fakultet, Zagreb.

Vukelić, J., Mikac, S., Baričević, D., Bakšić, D., Rosavec, R. (2008): Šumska staništa i šumske zajednice u Hrvatskoj, Nacionalna ekološka mreža. Državni zavod za zaštitu prirode, Zagreb. 